\title{
Larkspur Poison Weed: 100 Years of Delphinium Research
}

\section{By Benedict T. Green, Dale R. Gardner, James A. Pfister, and Daniel Cook}

I n 1909 the US Department of Agriculture (USDA) established a research station known as "Camp Delphinium" in the Gunnison National Forest near Gunnison, Colorado (Fig. 1). The purpose of this station, under the direction of Dr C. D. Marsh, was to study and find solutions to larkspur poisoning in cattle. As a result of this work, Farmers Bulletin 531, entitled Larkspur or "Poison Weed," was published in 1916 detailing the current knowledge of larkspur intoxication in livestock, including management recommendations and treatment of intoxicated animals. Although much has changed in the livestock industry since 1909, larkspur poisoning is still a significant problem on ranges where it occurs. During the 100 years since the beginning of larkspur research by the USDA, numerous studies have been undertaken to "solve" the problem of larkspur poisoning in cattle, culminating in work currently underway at the Agricultural Research Service's Poisonous Plant Research Laboratory (PPRL) in Logan, Utah. The purpose of this article is to review important past findings and to highlight current research on larkspur at the PPRL.

Delpbinium (larkspur) species are members of the Ranunculacae family of plants that are commonly known as the buttercup family. Toxic larkspurs are found in the High Plains, foothill, and mountain rangelands of the western United States. The toxins in larkspurs are alkaloids, nitrogen-based compounds with potent pharmacological effects. Although the scope of the problem caused by toxic larkspur varies from year to year, the overall losses of cattle due to larkspur have remained remarkably consistent over time. For example, Marsh et al. ${ }^{1}$ described losses averaging $5 \%$ with some ranchers losing up to 200 head in a single season. More recently Pfister et $\mathrm{al}^{2}{ }^{2}$ have documented losses ranging from $2 \%$ to $5 \%$ and as high as $15 \%$ in places with large stands of toxic larkspur. Although the death of livestock is an obvious contribution to total dollar value losses, there are additional factors that must be considered. For example, stocker cattle grazing on typical rangeland where toxic larkspur grows have the potential to gain up to 2.5 pounds per day $(1.1 \mathrm{~kg} /$ day $)$, and many producers, upon losing animals to larkspur, move them off ranges that have high-quality forage. This results in significant amounts of wasted high-quality forage and increased feeding costs. Other hidden costs include the loss of lactating cows from larkspur poisoning. The loss of a cow typically leaves an early weaned, poorly performing calf and requires a replacement cow or heifer to be found if herd numbers are to stay constant.

\section{Geographical Range and Delphinium Species of Importance}

In the western United States, larkspur species have been organized into three basic categories: plains, low, and tall, based upon mature plant height and geographic distribution. ${ }^{2}$ The most significant larkspur species and their associated plant communities are described in Table 1.

Plains or Geyer's larkspur (Delphinium geyeri), shown in Figure 2A, grows primarily on foothill and short grass prairie ranges in Wyoming, Colorado, and northern New Mexico and can be a problem for ranchers where it occurs. Plains larkspur is a perennial that begins growth early in the spring and can reach a height of 36 inches. Because of the early spring growth of this plant it may be consumed by cattle before other green forage is available and cause poisonings. Alkaloids commonly found in plains larkspur include browniine, 14-acetylbrowniine, and geyerine.

Low larkspurs (Delphinium nuttalianum, Delphinium bicolor, and Delphinium andersonii), shown in Figure 2B, grow on foothill and mountain ranges. Low larkspurs have fine leaves, may reach a maximum height of 4-30 inches $(10-76 \mathrm{~cm})$, and grow from the spring into summer before senescing. Low larkspur populations tend to increase in response to cool and wet winter and spring climate conditions. During years with cool, wet weather conditions, 


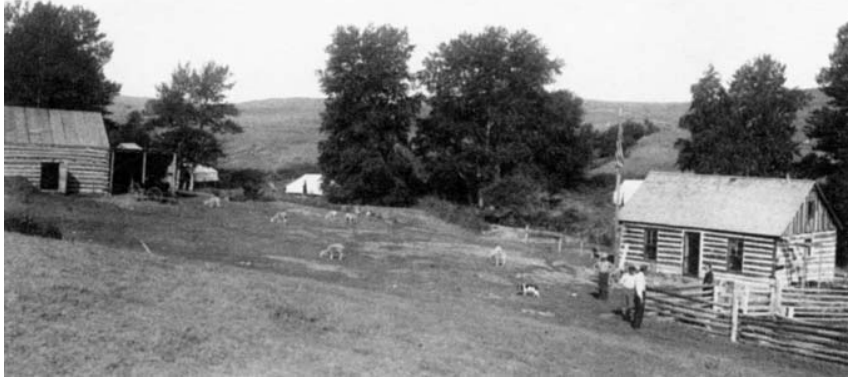

Figure 1. Camp Delphinium, Gunnison, Colorado, 1 September 1909.

the growth of grasses that cattle would normally graze may be low, and the density of low larkspur may be high, resulting in increased consumption by cattle. Some alkaloids of significance found in low larkspur are methyllycaconitine and nudicauline. ${ }^{2}$

Tall larkspurs of economic importance (Delphinium glaucum, Delphinium barbeyi, Delphinium glaucescens, and Delphinium occidentale) are widely distributed, long-lived perennial plants that begin rapid growth when snow recedes in the spring and early summer. An image of $D$. barbeyi is shown in Figure 2C, and the geographic distribution of major tall larkspur species is depicted in Figure 3. Tall larkspurs have multiple hollow stems, with wide-bladed leaves growing from slender leaf stalks. In the spring and early summer, larkspurs send up stalks 18-24 inches (46-61 cm) in height and form bud clusters that grow to $36-72$ inches $(91-183 \mathrm{~cm})$ tall and have a characteristic spur on the flower. After the bud cluster is fully formed, tall larkspurs begin rapid elongation of flowering stalks. This elongation may take one to several weeks, depending on temperature and soil moisture. The entire growth process takes about 50 days for tall larkspurs to gain their maximum height and flower. Flowering usually begins when the plants have gained $>80 \%$ of their maximum height, and at 9,500foot elevation $(1,981 \mathrm{~m})$ typically occurs in mid- to late July, with the end of flowering occurring about three weeks later. Seed pods typically begin formation by the end of July and early August from mature flowers. Pods develop gradually over the course of several weeks and generally are completely mature in August or September, depending on elevation and temperature. The mature pods begin to dry, and eventually the mature seed will be dispersed as the pods split open. Like low larkspur, tall larkspur growth is sensitive to climate, including such factors as snowpack depth, and is positively correlated with the number of shoots formed in the spring. Some alkaloids of significance found in tall larkspur species

\begin{tabular}{|c|c|c|c|c|}
\hline $\begin{array}{l}\text { Class/species (common } \\
\text { name) }\end{array}$ & $\begin{array}{l}\text { Height at } \\
\text { maturity }(\mathrm{cm})\end{array}$ & $\begin{array}{l}\text { Elevation } \\
\quad(\mathrm{m})\end{array}$ & $\begin{array}{l}\text { Associated plant } \\
\text { communities }\end{array}$ & $\begin{array}{l}\text { Typical risk of } \\
\text { losses }\end{array}$ \\
\hline \multicolumn{5}{|l|}{ Tall larkspurs } \\
\hline $\begin{array}{l}\text { D. glaucum } \\
\text { (sierra larkspur) }\end{array}$ & $90-200$ & $>2,000$ & Aspen, conifers, alpine meadows & Low \\
\hline $\begin{array}{l}\text { D. barbeyi } \\
\text { (subalpine larkspur) }\end{array}$ & $90-180$ & $>2,000$ & $\begin{array}{l}\text { Aspen, conifers, alpine meadows, } \\
\text { mountain brush, alpine tundra }\end{array}$ & $\begin{array}{l}\text { Moderate to } \\
\text { severe }\end{array}$ \\
\hline $\begin{array}{l}\text { D. glaucescens } \\
\text { (smooth larkspur) }\end{array}$ & $76-90$ & $>2,000$ & Mountain meadows, sagebrush & Low to moderate \\
\hline $\begin{array}{l}\text { D. occidentale } \\
\text { (subalpine larkspur) }\end{array}$ & $90-180$ & $>2,000$ & $\begin{array}{l}\text { Mountain brush, sagebrush, } \\
\text { conifer, aspen }\end{array}$ & Low to severe \\
\hline \multicolumn{5}{|l|}{ Low larkspurs } \\
\hline $\begin{array}{l}\text { D. nuttallianum } \\
\text { (twolobe larkspur) }\end{array}$ & $20-60$ & $>1,200$ & $\begin{array}{l}\text { Mountain brush, sagebrush, } \\
\text { conifer, aspen }\end{array}$ & \\
\hline $\begin{array}{l}\text { D. bicolor } \\
\text { (little larkspur) }\end{array}$ & $20-40$ & $>800$ & Mountain brush, sagebrush & \\
\hline $\begin{array}{l}\text { D. andersonii } \\
\text { (Andersons's larkspur) }\end{array}$ & $10-60$ & $>1,200$ & $\begin{array}{l}\text { Desert shrub, mountain brush, } \\
\text { sagebrush, pinion-juniper }\end{array}$ & \\
\hline \multicolumn{5}{|l|}{ Plains larkspur } \\
\hline $\begin{array}{l}\text { D. geyeri } \\
\text { (Geyer's larkspur) }\end{array}$ & $40-80$ & $>1,500$ & $\begin{array}{l}\text { Desert shrub, mountain brush, } \\
\text { sagebrush, shortgrass prairie }\end{array}$ & \\
\hline
\end{tabular}



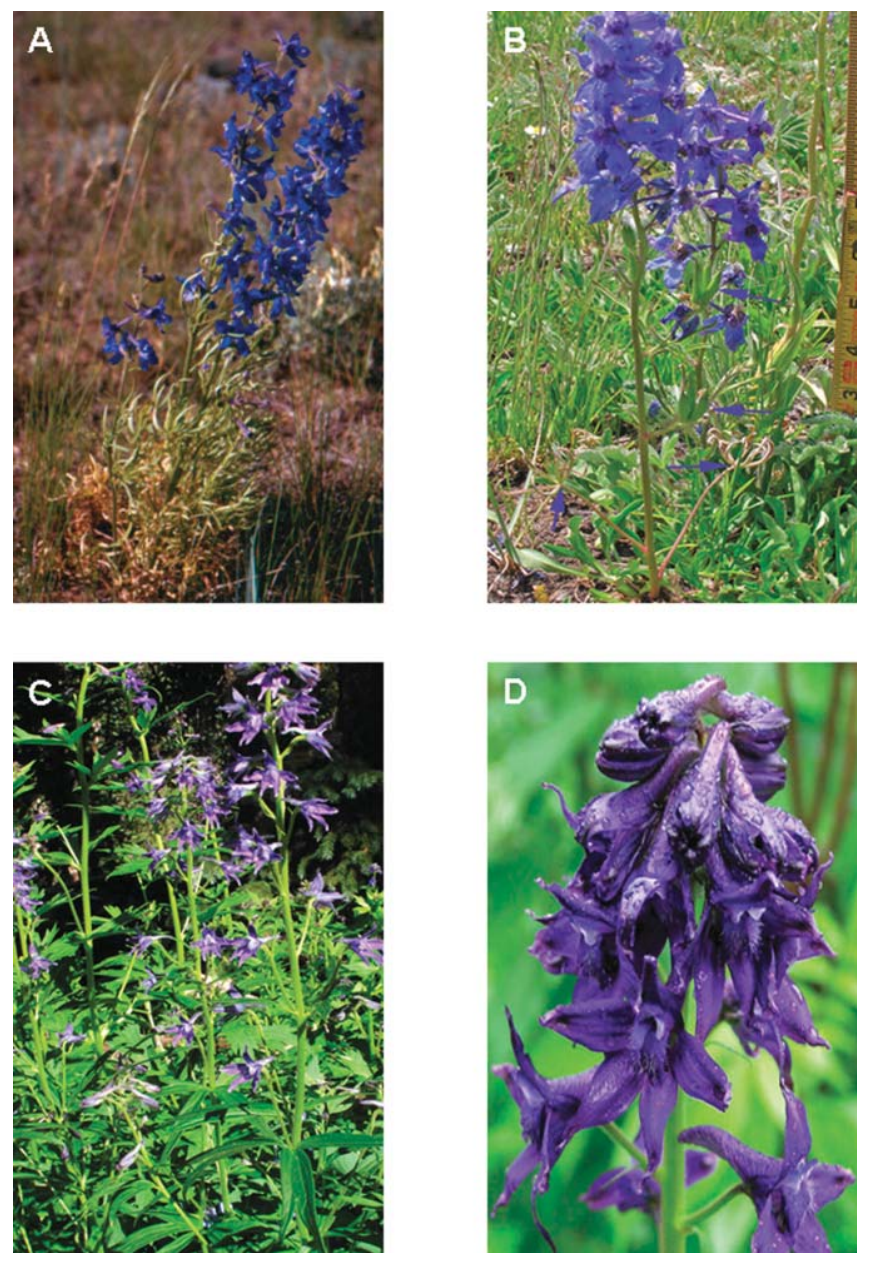

Figure 2. Images of (A) plains larkspur (D. geyeri), (B) low larkspur (Delphinium nuttallianum), (C) tall larkspur (D. barbeyi), and (D) detail of tall larkspur flower. Images B-D courtesy of Al Schneider, (C) www. swcoloradowildflowers.com.

are methyllycaconitine, deltaline, and dictyocarpine. ${ }^{2}$ These alkaloids vary by location. For example, Delphinium occidentale (duncecap larkspur) has two chemotypes (populations with different chemical profiles) that differ in biogeographical distribution and toxicity. Knowledge of specific alkaloid content is important because the toxicity of larkspur varies between species and locations.

\section{Mechanism of Intoxication}

Toxic larkspur species produce more than 18 different toxic alkaloids, which can be classified into two types: the MSAL-type and MDL-type alkaloids. Two common high-abundance alkaloids found in larkspur are methyllycaconitine (MLA), a MSAL-type alkaloid, and deltaline, an MDL-type alkaloid. MLA has a lethal dose of $4.5 \mathrm{mg} / \mathrm{kg}$ in mice, and deltaline has a lethal dose of $200 \mathrm{mg} / \mathrm{kg}$ in mice. A lethal dose is defined as a dose that will kill $50 \%$ of animals. Because MLA is the most toxic, it has been used for the prediction of plant toxicity. ${ }^{2}$ Moreover, these

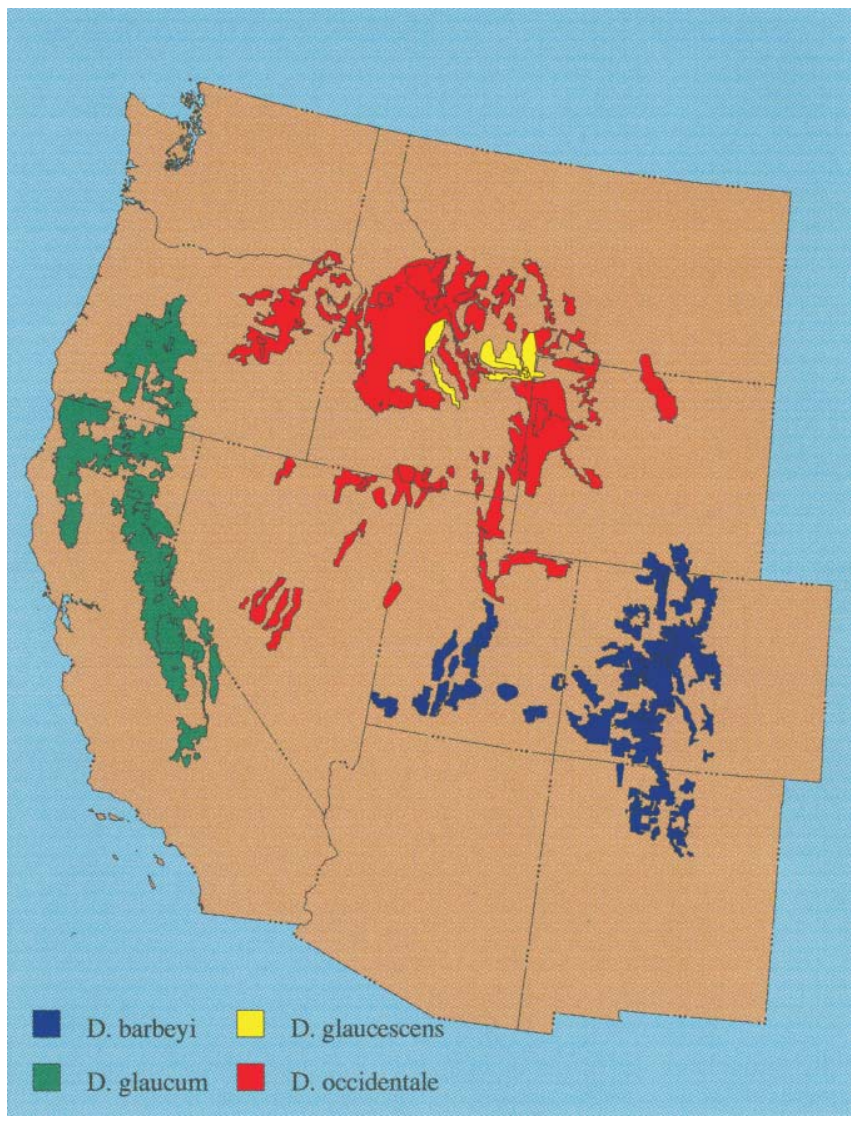

Figure 3. Distribution of the major tall larkspurs in the western United States.

alkaloids are potent blockers of acetylcholine receptors found in the nervous system and skeletal muscle. In poisoned animals these alkaloids bind to these receptors in muscle and prevent the neurotransmitter acetylcholine from activating the receptor, which results in muscle fatigue and weakness (Fig. 4), as manifested by tremors and inability to stand.

\section{Clinical Signs}

Cattle poisoned by larkspur typically show the following clinical signs: muscle weakness and trembling, rapid heart rate, failure of voluntary muscular coordination, inability to defecate, sternal recumbency (i.e., lying on brisket and unable to stand) followed by lateral recumbency (i.e., unable to maintain an upright posture even when lying down), bloating, inability to breathe, and death. ${ }^{2}$ The progression of these signs is often rapid and may not be observed because poisoned animals are commonly found dead. In addition to these well-documented clinical signs of poisoning, recent research at the PPRL has identified less obvious dose-dependent changes in heart rate and changes in muscle response. These changes are detectable at low doses within 24 hours after poisoning when other signs are minimal or not present. 

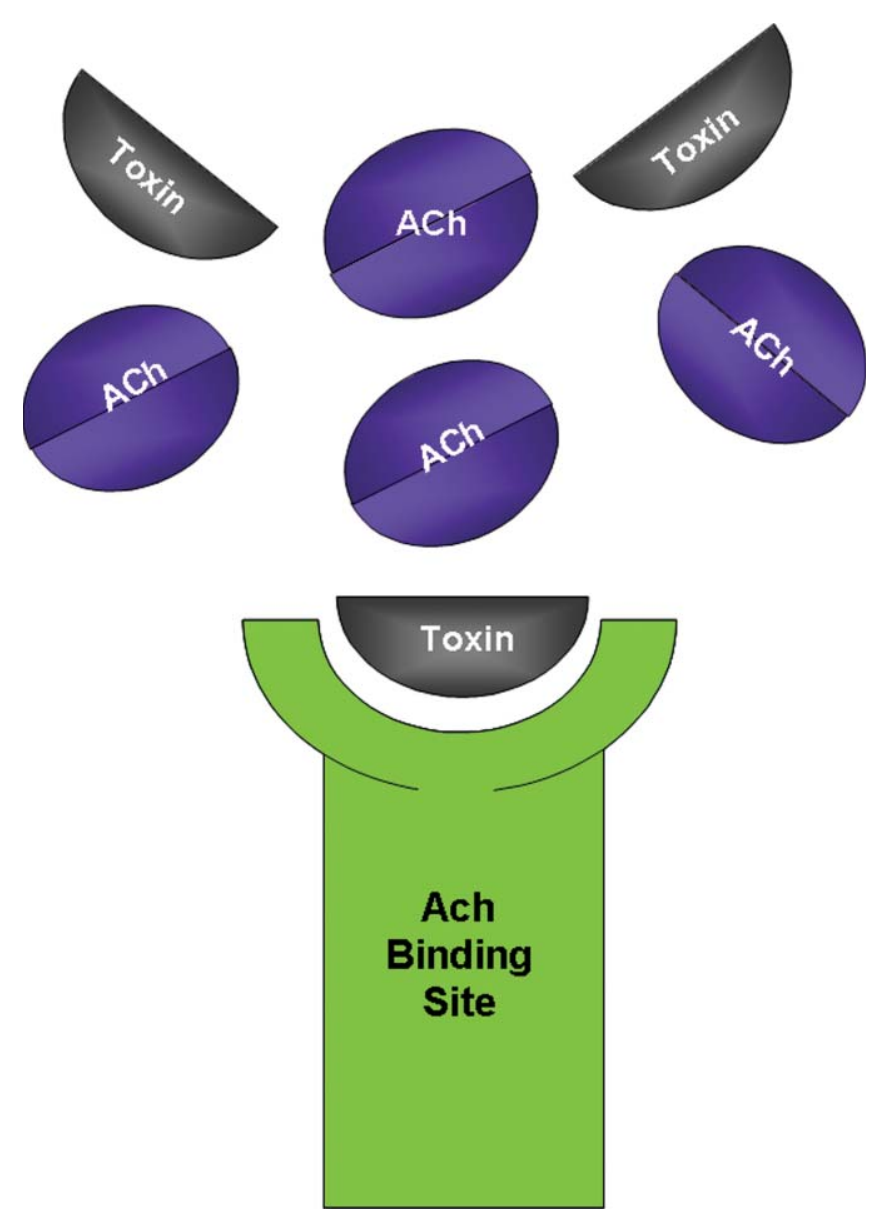

Figure 4. The classical model of drug-receptor interactions depicting the competition between acetylcholine and larkspur toxins at acetylcholine receptors in muscle. The receptor binding site is depicted in green. Acetylcholine is represented as blue circles and larkspur toxins as grey half circles. Although the larkspur toxins can tightly bind to and block the acetylcholine binding site, they lack the correct structure to activate the receptor and as a result cause muscle weakness.

Research at the PPRL has shown that as the dose of larkspur alkaloids administered to cattle is increased, heart rate increases, plateaus, and then decreases. Once an equivalent dose of $12 \mathrm{mg} / \mathrm{kg}$ MSAL-type alkaloids in cattle is exceeded, significant muscle weakness is also observed. For example, in three heifers dosed with $15 \mathrm{mg} / \mathrm{kg}$ MSALtype alkaloids, which caused collapse to sternal or lateral recumbency, the heifers were given an intramuscular dose of $0.02 \mathrm{mg} / \mathrm{kg}$ neostigmine as a drug rescue. This resulted in all three animals standing within 15 minutes. The drug neostigmine inhibits a key enzyme so that the larkspur toxin is partially neutralized at the nerve-muscle junction. In addition to rescuing recumbent cattle, neostigmine was also effective at reversing the effects of a $12 \mathrm{mg} / \mathrm{kg}$ MSAL-type alkaloid dose on heart rate. The use of neostigmine for the reversal of recumbency, and most importantly lateral recumbency, may provide a means to alter the outcome of larkspur poisoning. Further research is needed to investigate the utility of neostigmine alone and in combination with other drugs such as the closely related drug physostigmine in laboratory and field applications and to investigate the reversal of MSAL-type alkaloid toxicity in cattle that have ingested lethal amounts of plant material.

\section{Clearance Times of Toxic Larkspur Alkaloids}

In addition to investigations of the physiological responses of cattle to toxic larkspur alkaloids, recent work at the PPRL has focused on the determination of the clearance times from tissue of toxic larkspur alkaloids in cattle. Cattle were given an equivalent dose of two toxic alkaloids and monitored for 96 hours. The blood concentrations of the alkaloids peaked at 10 and 6 hours after dosing, and the heart rate peaked at 17 hours. By 96 hours the concentration in the blood of one alkaloid was very low, and the blood concentration of the second alkaloid was below the limit of detection. This research suggests that 144 hours or six days of clearance time is needed for $99 \%$ elimination of toxic alkaloids from the blood.

\section{Alkaloid Composition and Toxicity}

Populations of tall larkspur high in MLA are the most problematic to ranchers. Unfortunately MLA is not the only toxic alkaloid found in larkspur. With this observation in mind, current research at the PPRL is designed to determine the contributions of other alkaloids in the overall toxicity of larkspur. For example, the effects of MDL-type (less toxic) alkaloids on the toxicity of MLA (a more toxic MSAL-type alkaloid) were assessed in mice individually and in combination with MLA. This research suggests that in plants containing large quantities of less toxic alkaloids, the total alkaloid content and not just MLA should be considered when predicting the toxic potential. Similar experiments are currently being performed in cattle to verify these results.

\section{Cattle Grazing of Larkspur}

Current management recommendations for grazing cattle on larkspur-containing ranges are based primarily on the concentration of MSAL-type alkaloids in the larkspur. ${ }^{2}$ The two most important factors that determine if cattle grazing larkspur become poisoned are how much larkspur is eaten and how fast larkspur is consumed. Studies done at the PPRL on cattle grazing larkspur have shown that cattle will readily consume tall larkspur during summer storms. Cattle begin to consume tall larkspur once it starts to flower and as the plant matures to the pod stage (Fig. 2D). It is typically in the pod stage during late summer that cattle eat large quantities of larkspur. Research suggests that cattle prefer the pods over the flowers. ${ }^{2}$ Studies at the PPRL using both fresh and dried larkspur have shown that the amount of toxic alkaloids in larkspur does not change the amount cattle eat and that cattle will readily consume plants that are either high or low in toxic alkaloids without hesitation. ${ }^{2}$ 


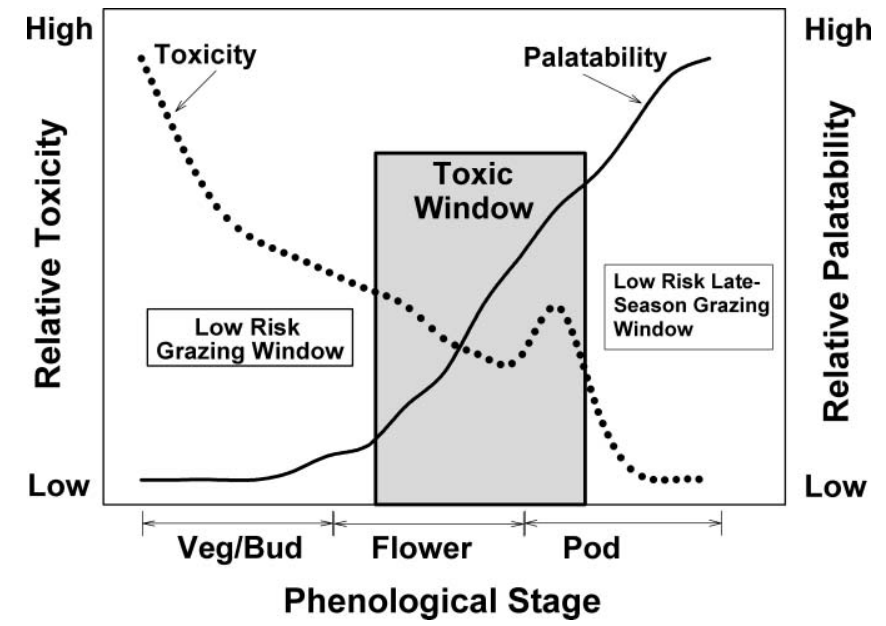

Figure 5. The relationship between toxicity and palatability in tall larkspurs. Most cattle deaths occur during the toxic window when the concentration of toxic alkaloids is substantial, and consumption by cattle begins to increase after flowering racemes elongate. There is a low-risk grazing window early in the season before flowering when larkspur is generally very toxic, but risk is low because cattle eat little or no tall larkspur.

As early as 1916 Marsh and Clawson recognized that tall larkspur is most toxic early in the season and that the toxicity decreases as the plants mature. The period of highest toxicity and greatest danger to cattle has been termed the toxic window (Fig. 5). The toxic window starts at the flower stage and ends in the pod stage for about five weeks of elevated toxicity depending on moisture, temperature, and elevation. The most prudent grazing scheme on larkspur ranges is one that manages cattle grazing around the toxic window and is based upon the growth stage of the larkspur. This is done by 1) grazing early in the summer until the larkspur flowers (typically 4-6 weeks depending on elevation and weather), 2) if possible, remove livestock from infested rangelands during the high-risk flower and early pod stages of larkspur growth (4-5 weeks), and 3) graze late in the season when the pods begin to shatter ( $4-5$ weeks).

\section{Herbicide Control}

Studies on the herbicide control of two economically significant larkspur species, duncecap larkspur (D. occidentale) and subalpine larkspur (D. barbeyi), have shown that although larkspur can be difficult to control, if the density is reduced through the use of herbicides, cattle death losses can also be reduced. Studies on the use of herbicides for the control of duncecap and subalpine larkspur have shown that the time of application is critical for effective control. For duncecap and subalpine larkspurs, Escort ${ }^{\mathrm{TM}}$ and Tordon ${ }^{\mathrm{TM}}$ have been shown to be effective but must be applied in the early vegetation stages at rates listed in Table 2. Caution must be used when applying herbicides in pastures where cattle are to be grazed because of reports that larkspur plants may become more palatable after herbicide application. ${ }^{3}$ Less work has been done on the herbicide control of low and plains larkspur, although 2,4-D ${ }^{\mathrm{TM}}$ and picloram have been shown to be effective at controlling low and plains larkspur. Application rates and time of application are presented in Table 3.

\section{Other Management Options}

In addition to grazing management of cattle, other management options are available to ranchers to reduce the impact of cattle grazing larkspur. Cattle can be averted to larkspur by feeding them the plant, and then dosing with $200 \mathrm{mg} / \mathrm{kg}$ body weight of lithium chloride, which causes nausea that

\section{Table 2. Herbicidal control of tall larkspur}

\begin{tabular}{|c|c|c|c|c|}
\hline \multirow[b]{2}{*}{ Herbicide } & \multicolumn{2}{|c|}{ D. occidentale } & \multicolumn{2}{|c|}{ D. barbeyi } \\
\hline & Rate & Stage & Rate & Stage \\
\hline Escort & $\begin{array}{l}0.5-1 \text { ounces ai/A } \\
(0.8-1.6 \text { ounces/A) }\end{array}$ & Vegetative & $\begin{array}{l}2 \text { ounces ai/A } \\
(3.3 \text { ounces/A) }\end{array}$ & Vegetative, bud \\
\hline Tordon & $\begin{array}{l}1 \text { pound ae/A ( } 2 \text { quarts/A) } \\
2 \text { pounds ae/A ( } 1 \text { gallon/A) }\end{array}$ & $\begin{array}{l}\text { Vegetative } \\
\text { Bud-flower }\end{array}$ & $\begin{array}{l}1 \text { pound ae/A ( } 2 \text { quarts/A) } \\
2 \text { pounds ae/A ( } 1 \text { gallon/A) }\end{array}$ & $\begin{array}{l}\text { Bud-flower } \\
\text { Vegetative }\end{array}$ \\
\hline
\end{tabular}

Table 3. Herbicidal control of plains and low larkspur

\begin{tabular}{|c|c|c|c|c|}
\hline \multirow[b]{2}{*}{ Herbicide } & \multicolumn{2}{|c|}{ Low larkspur (D. nelsonii) } & \multicolumn{2}{|c|}{ Plains larkspur (D. geyeri) } \\
\hline & Rate & Stage & Rate & Stage \\
\hline 2,4-D & $1.5-3$ pounds ai/A & Fully emerged before flowering & N.A. & N.A. \\
\hline Picloram + 2,4-D & N.A. & N.A. & $0.25-0.5,0.5$ & Bud \\
\hline
\end{tabular}


the cattle associate with eating larkspur. ${ }^{4}$ The aversion has been shown to last for three years but is susceptible to social facilitation, whereby other nonaverted cattle may influence the averted animal to eat larkspur. In ranges where tall larkspur grows in dense patches, sheep can be used to reduce the density and acceptability of tall larkspur to cattle. If the aversion of cattle to larkspur is not practical for a rancher, then drug treatment of poisoned animals is another option. If cattle that have consumed larkspur can be found in time, drugs such as physostigmine given intravenously at $0.08 \mathrm{mg} / \mathrm{kg}$ will reverse the toxic effects of the plant. ${ }^{2}$ Recent work at the PPRL has shown that neostigmine given intramuscularly at a dose of $0.02 \mathrm{mg} / \mathrm{kg}$ can also be used as a drug rescue for poisoned cattle. Neostigmine is approved for veterinary use, and intramuscular dosing is much easier in field situations. Finally, mineral supplementation has been suggested as a means to reduce losses. No experimental evidence exists to support the feeding of specially formulated mineral salt supplements to cattle grazing larkspur-containing ranges. ${ }^{2}$ Grazing studies of cattle dosed with mineral salts did not change the amount of larkspur consumed by cattle. Therefore, mineral supplements should be fed to meet nutritional needs but are not a recommended management strategy for larkspur poisoning.

\section{Conclusions}

Larkspur has been the subject of research by the USDA for 100 years. Recent work at the PPRL has focused on dose-response studies of larkspur alkaloids, developing drug therapies, the clearance of larkspur toxins from cattle, and alkaloid composition. The purpose of this research has been to allow for the improved management of grazing cattle and effective treatments for poisoned animals where larkspur grows. Larkspur has been and will continue to be a problem for ranchers in the western United States. Research at the PPRL in Logan, Utah, is continuing with the ultimate goal of reducing risk and cattle losses for livestock enterprises with "larkspur problems" in the West.

\section{Acknowledgments}

The authors thank Carol Chitko-McKown and Mark Rutherford for their critical review of the manuscript. The authors thank Anita McCollum and Terrie Wierenga for help with the figures and comments regarding this manuscript. The authors thank Kermit Price, Scott Larsen, Andrea Dolbear, Clint Stonecipher, Ed Knoppel, Joseph Jacobsen, Katie Lott, Jessie Roper, Kendra Dewey, Danny Hansen, Rex Probst, and Al Maciulis for their help with past larkspur experiments.

\section{References}

1. Marsh, C. D., A. B. Clawson, and H. Marsh. 1916. Larkspur poisoning of livestock. Washington, DC, USA: US Department of Agriculture, Bureau of Animal Industry Bulletin 365. p. 1-12.

2. Pfister, J. A., D. R. Gardner, K. E. Panter, G. D. Manners, M. H. Ralphs, B. L. Stegelmeier, and T. K. Schoch. 1999. Larkspur (Delphinium spp.) poisoning in livestock. Journal of Natural Toxins 8:81-94.

3. Ralphs, M. H., G. D. Manners, and D. R. Gardner. 1998. Toxic alkaloid response to herbicides used to control tall larkspur. Weed Science 46:116-119.

4. Ralphs, M. H., and C. D. Cheney. 1993. Influence of cattle age, lithium chloride dose level and food type in the retention of food aversions. Journal of Animal Science 71:373-379.

\section{Additional Reading}

Ralphs, M. H., J. E. Bowns, and G. D. Manners. 1991. Utilization of larkspur by sheep. Journal of Range Management 44:619-622.

Authors are Research Pharmacologist (Green), Research Chemist (Gardner), Rangeland Scientist, jim.pfister@ars.usda.gov (Pfister), and Plant Physiologist (Cook), Poisonous Plant Research Laboratory, Agricultural Research Service, United States Dept of Agriculture, 1150 E 1400 N, Logan, UT 84341, USA. Published with the approval of the Director as Journal Paper No. 8038 of the Utah Agricultural Experiment Station. 